\title{
DIURNAL COMPONENT IN THE RESPONSE BY THE MOUSE TO GONADOTROPHIN
}

\author{
B. M. BINDON AND D. R. LAMOND \\ C.S.I.R.O. Division of Animal Physiology, Cunningham Laboratory, \\ St. Lucia, Queensland, Australia
}

(Received 29th September 1965)

\begin{abstract}
Summary. The uterine weight and ovulation responses of immature intact and hypophysectomized mice from two lighting regimes have been studied after injection of gonadotrophin. The results indicate diurnal variation in ovarian response: the response to gonadotrophin was greater when it was administered during the second half of the light phase of the daily light cycle than at any other time.

Pregnant mice were fasted for 36 - to 48 -hr periods beginning at 06.00 hours or 18.00 hours on the 2 nd, 3rd or 4 th day after mating. Diurnal variation in the proportion of pregnancies failing was demonstrated. The effect was not attributable to differences in loss of body weight during fasting, and could be prevented by injections of human chorionic gonadotrophin (HCG).

The numbers of eggs ovulated by adult di-oestrous mice treated with HGG were studied after 36- or 48-hr fasts commencing at 06.00 hours or 18.00 hours 2 days before an injection of HCG. Fasting reduced numbers of ovulations, but the effect was influenced by the time of day when the fast began. Reversal of the lighting regime resulted in a reversal of the pattern.
\end{abstract}

\section{INTRODUCTION}

Lamond \& Bindon (1966a) observed diurnal variation in the uterine weight response by the immature mouse injected with human chorionic gonadotrophin (HCG) at the time of hypophysectomy. Lamond \& Braden (1959) had shown similar variation in the response to gonadotrophin by the intact immature mouse.

The studies of Everett \& Sawyer (1950) and Everett (1956) suggested that in rats kept under controlled conditions ovulating hormone is released by the pituitary gland during the period 14.00 to 16.00 hours on the afternoon of pro-oestrus. McCormack \& Meyer (1962) also showed, in experiments employing hypophysectomy and the use of barbiturates, that ovulating hormone was released in the early afternoon on the 24th day of life of the rat. Clark \& Baker (1964) reported diurnal differences in pituitary prolactin concentration in the rat with a peak in mid-afternoon.

It was decided to investigate diurnal variation in ovarian function in the 
mouse in relation to the daily lighting schedule. Uterine weight and numbers of eggs ovulated were, therefore, studied in hypophysectomized immature mice kept under different lighting regimes and injected with gonadotrophin at different times of day. Another parameter studied was failure of pregnancy following fasting, which appears to have as its basis depression or failure of pituitary gonadotrophic function (McClure, 1961).

\section{MATERIALS AND METHODS}

Studies with different lighting regimes

Pregnant mice of the Sydney White strain, of similar ages and breeding histories, were allotted to two breeding rooms of similar size and structure and with similar conditions of temperature and humidity. In one room the lights were on from 06.00 to 18.00 hours (normal) and in the other they were on from 18.00 to 06.00 hours (reversed); during the remainder of each day the rooms were in darkness. The mice were disturbed for routine management procedures soon after the lights came on. Male offspring were removed at birth. Female offspring were weaned at 18 to 20 days of age, when they weighed 11 to $13 \mathrm{~g}$, and were used in experiments on the following day.

\section{Fasting studies}

Randomly-bred virgin albino mice, aged 8 to 9 weeks, were placed in groups of three with a single male. They were examined for evidence of mating at 09.00 hours daily, and were transferred individually to small cages on the day of appearance of the vaginal plug.

The animals were fed on unlimited mouse cubes while caged with males and during pre-experimental periods. Fasting treatments were begun by removing the cubes from the wire basket and replacing sawdust inside the cage. Drinkingwater was available throughout, and at the end of each fast the mouse cubes were replaced in the feed basket. Mice remained in their individual cages until they were killed 9 to 10 days after mating.

Unfasted control mice were always disturbed to the same extent as fasted animals; for example, the sawdust was changed in the cages of control mice at a similar time to the fasted groups.

\section{RESULTS}

The effect of the light-cycle on the uterine-weight response of intact and hypophysectomized mice to $\mathrm{HCG}$ administered at two times of day (Experiment A1)

Mice from both lighting regimes (normal and reversed) were injected 3 to $4 \mathrm{~min}$ after hypophysectomy, which was carried out at either 09.00 to 10.00 hours or 15.00 to 16.00 hours. Three dose levels, $0.33,1.0$ or 3.0 i.u., of HCG (Pregnyl-Organon Ltd) were administered to groups of six mice. Intact mice (five to each group), from both lighting regimes, were injected with these doses of HCG at the same times.

Hypophysectomized mice were placed in a box in which the temperature was kept at 26.5 to $28^{\circ} \mathrm{C}$. Intact mice were returned to their regular lighting 
regime. The mice were killed 44 to $48 \mathrm{hr}$ after injection, and body weights and wet uterine weights were recorded. The heads of all hypophysectomized mice were fixed in formalin and later microscopically examined at random; the results from mice with pituitary fragments were discarded.

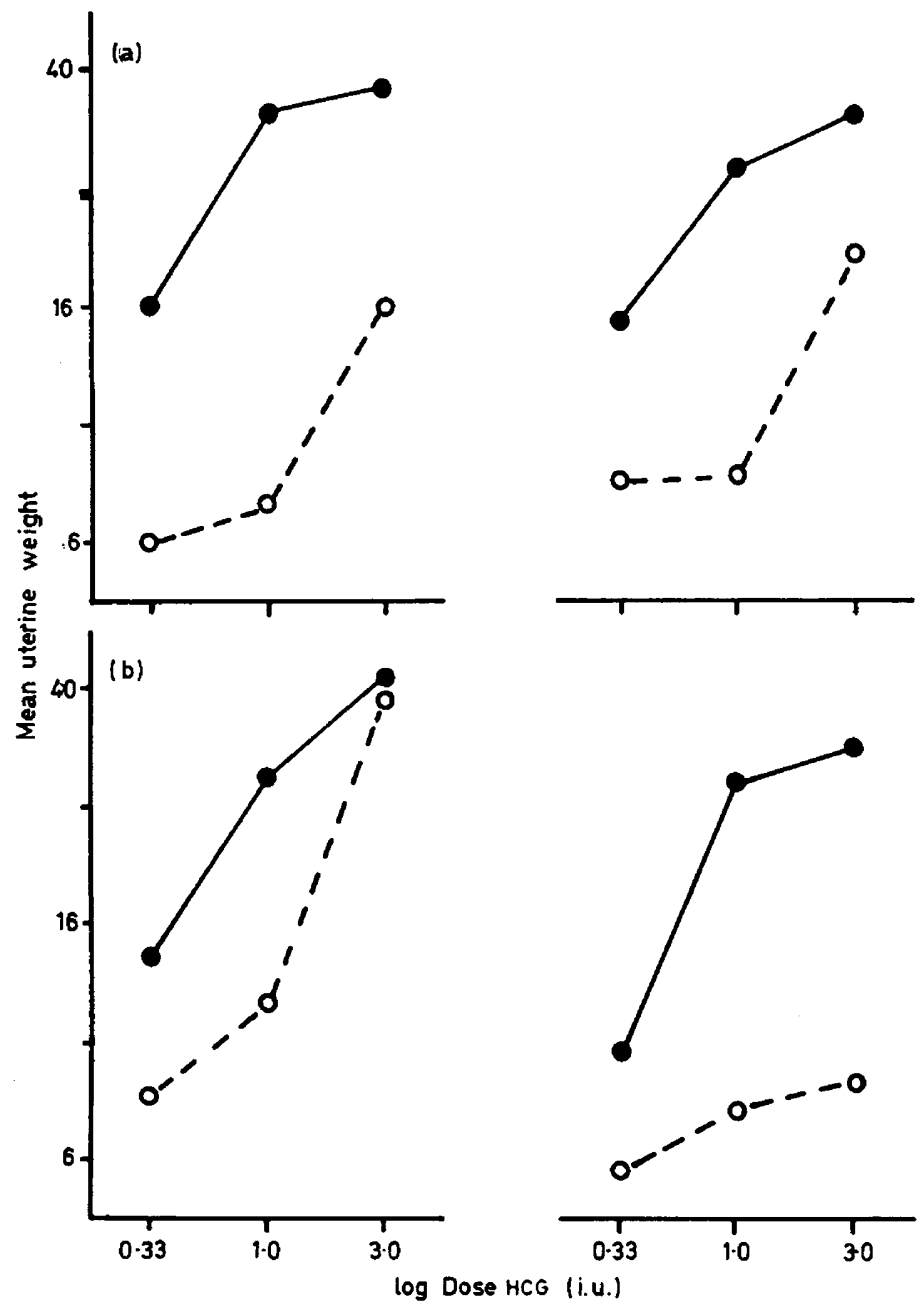

TexT-Fig. 1. Mean uterine weights (mg) of groups of mice from normal (left) and reversed (right) light cycles injected at (a) 09.00 to 10.00 hours, or (b) 15.00 to 16.00 hours with HCG, and killed 44 to $48 \mathrm{hr}$ later (Experiment A1). O, Intact mice; $O$, hypophysectomized mice.

The results are shown in Text-fig. 1. A summary of the analyses of variance of these results is presented in Table 1. Variation in response was greater in hypophysectomized than in intact mice, hence they were analysed separately. Only small differences occurred in intact mice. Uterine weights in mice reared under the normal lighting regime were greatest following hypophysectomy in the afternoon. The mice reared under the reversed lighting regime showed a lower response after afternoon as compared with morning hypophysectomy. 
Effect of the light-cycle on the response by intact and hypophysectomized mice to HCG administered at four times of day (Experiment A2)

The results of Experiment $\mathrm{Al}$ showed the absence of the afternoon increase in response by mice reared under a reversed lighting regime. It is logical to assume that in reversed-light animals the time of greatest response would be shifted in accordance with the alteration in the light-cycle. The present experiment was designed to test that possibility. The response to HCG, given at the time of hypophysectomy, was again employed.

TABLE 1

SUMMARY OF ANALYSES OF VARIANCE OF THE EFFECT OF GONADOTROPHIN (HCG) IN INTACT AND HYPOPHYSEGTOMIZED MIGE ON REVERSED LIGHT GYCLES AND INJECTED AT TWO TIMES OF THE DAY (EXPERIMENT AI)

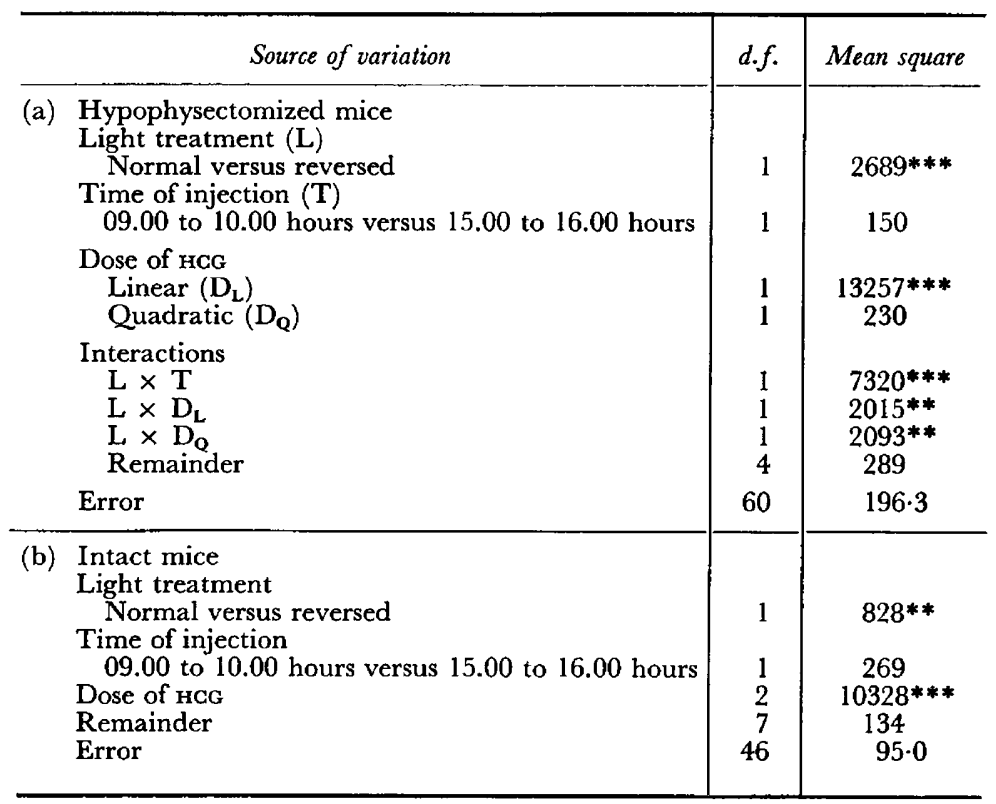

${ }^{* * 0.01}<P<0.05 ; * * * P<0.001$.

Intact mice received 0.33 or 1.0 i.u. and hypophysectomized mice received 1.0 or 3.0 i.u. of HCG at $05.00,08.00,17.00$ or 20.00 hours. There were four intact and five hypophysectomized mice in each group. Uterine weights were recorded at autopsy, 40 to $44 \mathrm{hr}$ after injection.

The results are shown in Text-fig. 2. A summary of the analysis of variance of the results, after correction for variation due to body weight differences, is shown in Table 2. As in the previous experiment, variances were greater in hypophysectomized mice. The response by intact mice was again largely independent of either time of day or lighting regime. Normal hypophysectomized mice showed the expected day-night differences, with increased response following hypophysectomy at 17.00 and 20.00 hours. The response of hypophysectomized mice from the reversed lighting regime showed an opposite pattern to that of the normal mice. 
Ovulation in mice from two lighting regimes (Experiment A3)

Intact or hypophysectomized mice from normal and reversed lighting regimes were primed at 16.00 hours on the day after weaning with 0.33 i.u. (intact mice) or 1.0 i.u. (hypophysectomized mice) of HCG. Hypophysectomy
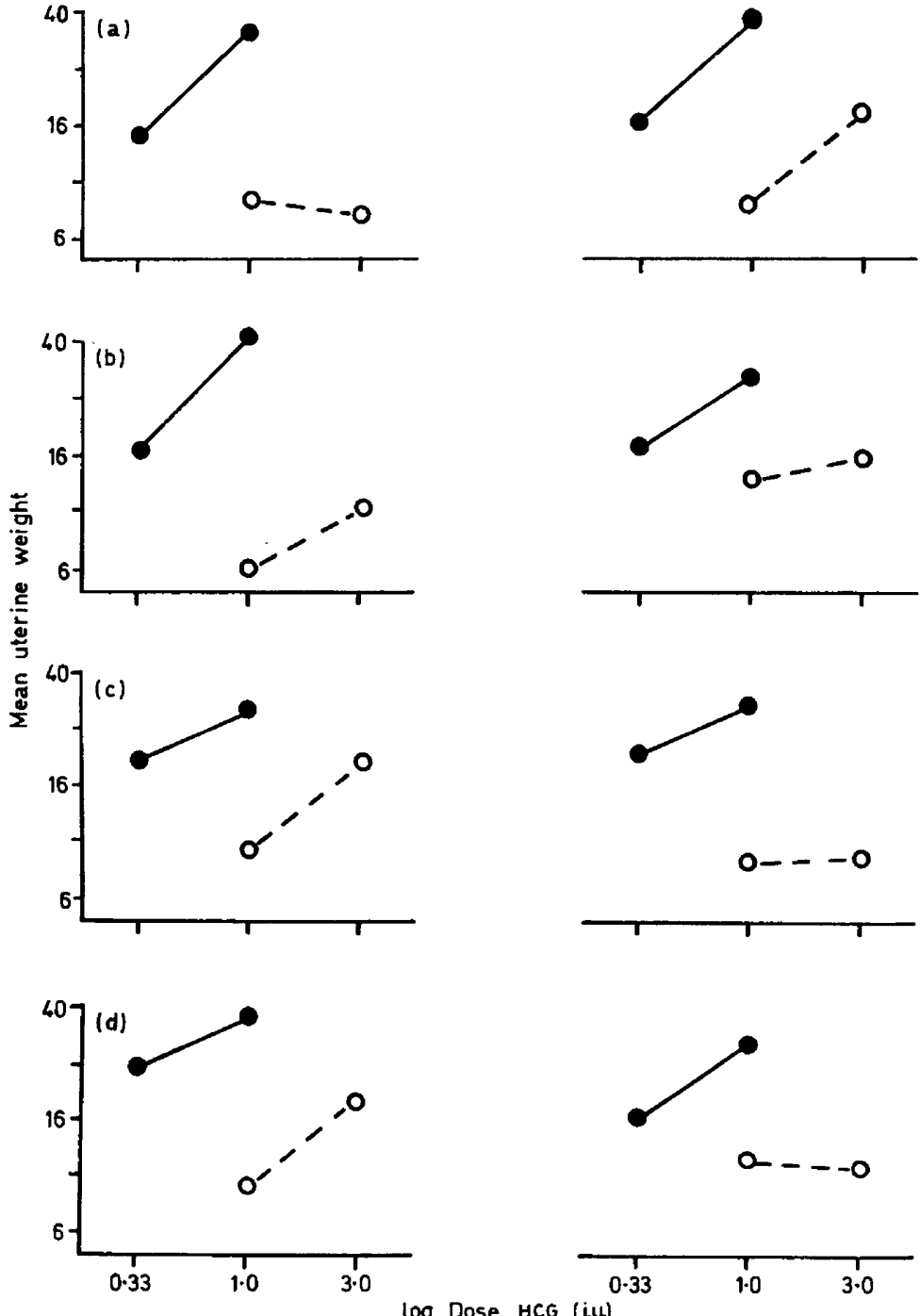

Texr-FIG. 2. Uterine weights (mg) after HCG in mice from normal (left) and reversed (right) light cycles following injection at four times during the day (Experiment A2) 0 , Intact mice; $O$, hypophysectomized mice. (a) 05.00 hours, (b) 08.00 hours, (c) 17.00 hours, (d) 20.00 hours.

was carried out 3 to $4 \mathrm{~min}$ before injection. Twenty-four hours later the intact mice (six per group) received $1 \cdot 1,3.3$ or $10.0 \mu \mathrm{g}$ of ovine luteinizing hormone, LH (NIH-LH-S5-National Institutes of Health, Bethesda, U.S.A.), and the hypophysectomized animals (six per group) received $3.3,10.0$ or $30.0 \mu \mathrm{g}$ of $\mathbf{~ L H . ~}$ The experiment was thus a $2 \times 2 \times 3$ factorial. All mice were killed $24 \mathrm{hr}$ after 
the injection of LH, and the numbers of ova in the ampulla of the oviduct were counted.

The results were transformed by adding 1 to the number of ova per mouse and taking the square root. An analysis of variance of the results for 3.3 and $10.0 \mu \mathrm{g} \mathrm{LH}$, summarized in Table 3, indicated a significant difference between

TABLE 2

SUMMARY OF ANALYSES OF VARIANCE OF THE EFFECT OF GONADOTROPHIN (HGG) IN INTACT AND HYPOPHYSEGTOMIZED MIGE ON REVERSED LIGHT GYGLES AND INJECTED AT FOUR TIMES OF THE DAY (EXPERIMENT A2)

\begin{tabular}{|c|c|c|c|}
\hline & Source of variation & d.f. & Mean square \\
\hline \multirow[t]{5}{*}{ (a) } & $\begin{array}{l}\text { Intact mice } \\
\text { Light treatment } \\
\text { Normal versus reversed }\end{array}$ & 1 & 113 \\
\hline & $\begin{array}{l}\text { Time of day } \\
\text { Linear }\left(T_{\mathrm{L}}\right) \\
\text { Quadratic } \\
\text { Cubic }\end{array}$ & $\begin{array}{l}1 \\
1 \\
1\end{array}$ & $\begin{array}{r}191 \\
2 \\
3\end{array}$ \\
\hline & Dose of HCG (D) & 1 & $11422 * * *$ \\
\hline & $\begin{array}{l}\text { Interactions } \\
T_{\mathrm{L}} \times \mathrm{D} \\
\text { Remainder }\end{array}$ & $\begin{array}{l}1 \\
9\end{array}$ & $\begin{array}{l}778^{*} \\
166\end{array}$ \\
\hline & Error & 47 & 138 \\
\hline \multirow[t]{5}{*}{ (b) } & $\begin{array}{l}\text { Hypophysectomized mice } \\
\text { Light treatment }(L) \\
\quad \text { Normal versus reversed }\end{array}$ & 1 & 344 \\
\hline & $\begin{array}{l}\text { Time of day } \\
\text { Linear }\left(T_{L}\right) \\
\text { Quadratic } \\
\text { Cubic }\left(T_{C}\right)\end{array}$ & $\begin{array}{l}1 \\
1 \\
1\end{array}$ & $\begin{array}{r}818 \\
2 \\
85\end{array}$ \\
\hline & Dose of HGG & 1 & $3990 * * *$ \\
\hline & $\begin{array}{c}\text { Interactions } \\
\mathbf{L} \times \mathrm{T}_{\mathrm{L}} \\
\mathbf{L} \times \mathrm{T}_{\mathrm{C}} \\
\text { Remainder }\end{array}$ & $\begin{array}{l}1 \\
1 \\
8\end{array}$ & $\begin{array}{l}3272 * * \\
3434 * * \\
205\end{array}$ \\
\hline & Error & 63 & $362 \cdot 0$ \\
\hline
\end{tabular}

$* 0.01<P<0.05 ; * * 0.001<P<0.01 ; * * * P<0.001$.

the effects of the two lighting regimes. The mice on the reversed lighting schedule, both intact and hypophysectomized, gave only negligible responses (Text-fig. 3).

The effect of time of commencement of fasting on pregnancy failure (Experiment B1)

A preliminary experiment (a), in which groups of mice were fasted for periods of $24 \mathrm{hr}$, beginning at either 06.00 or 18.00 hours on the 3rd day after mating (Day $0=$ day of appearance of the vaginal plug), revealed no evidence of pregnancy failure when the mice were killed on Day 10.

A second experiment (b) was designed so that mice were fasted for $36 \mathrm{hr}$, commencing at 18.00 hours on Day 2, at 06.00 or 18.00 hours on Day 3, or at 06.00 hours on Day 4. Each treatment group and a control group contained eleven mice. The animals were killed on Day 10 and the reproductive tracts 
examined for embryos. Pregnancy failure was recorded for those mice whose tracts contained no evidence of implantation and those with degenerating embryos.

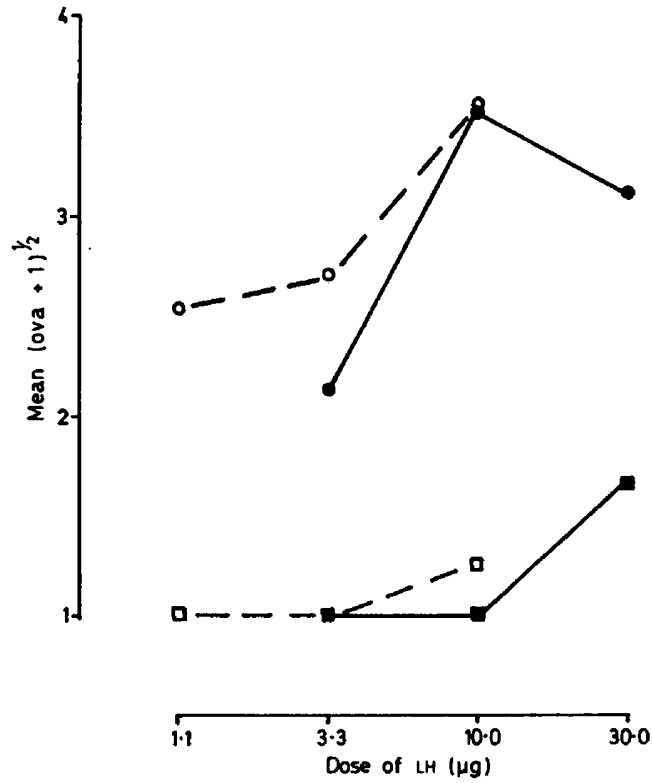

TExT-FIG. 3. Ovulation in immature mice reared under two lighting regimes. light, hypophysectomized mice; $\square$, reversed light, hypophysectomized mice; 0 , normal light, intact mice; $\square$, reversed light, intact mice.

TABLE 3

SUMMARY OF ANALYSIS OF VARIANCE OF NUMBERS OF OVULATIONS IN INTACT OR HYPOPHYSECTOMIZED MICE ON NORMAL OR REVERSED LIGHT GYCLES (EXPERIMENT A3)

\begin{tabular}{l|c|c}
\hline \multicolumn{1}{c|}{ Source of variation } & d.f. & Mean square \\
\hline Light regimes (L) & 1 & $80 \cdot 9 * * *$ \\
Intact versus hypophysectomized mice & 1 & $0 \cdot 6$ \\
Dose of LH (D) & 1 & $4 \cdot 6^{* *}$ \\
Interaction & 1 & $3 \cdot 1^{*}$ \\
L $\times$ D & 3 & $0 \cdot 2$ \\
Remainder & 40 & $0 \cdot 41$ \\
Error & & \\
\hline
\end{tabular}

${ }^{*} 0.01<P<0.05 ; * * 0.001<P<0.01 ; * * * P<0.001$.

The results of Experiment Bl(a) and a repeat study 1 month later [Experiment $\mathrm{B} 1(\mathrm{~b})]$ are presented in Table 4. In Experiment B1(b) additional groups were fasted for $48 \mathrm{hr}$, commencing at 06.00 or 18.00 hours on Day 3. All other details were as for Experiment B1(a). The results indicated that the effect of a 36-hr fast was dependent upon the time of day at which it began. Animals fasted for $48 \mathrm{hr}$ showed pregnancy failure similar to that described by McClure (1959).

The results of mice fasted for $36 \mathrm{hr}$, after transformation to angles, were 
submitted to analysis of variance (Table 5 ). The differences between experiments were not significant except for the 36 -hr fast starting at 06.00 hours on Day 4. A fast of $36 \mathrm{hr}$ which commenced at 18.00 hours on Day 2 or 3 was more effective in causing pregnancy failure than similar treatments begun at 06.00 hours on Day 3 or 4 .

TABLE 4

DIURNAL DIFFERENCES IN THE EFFEGT OF SHORT PERIODS OF FASTING ON FERTILITY (EXPERIMENTS Bl a AND b)

\begin{tabular}{|c|c|c|c|}
\hline \multirow{2}{*}{ Fasting treatment } & \multicolumn{3}{|c|}{$\begin{array}{c}\text { Proportion and percentage of females } \\
\text { pregnant at } 10 \text { days } *\end{array}$} \\
\hline & $\begin{array}{l}\text { Experiment } \\
\qquad B 1(a)\end{array}$ & $\begin{array}{l}\text { Experiment } \\
B 1(b)\end{array}$ & $\begin{array}{l}\text { Pooled } \\
\text { values }\end{array}$ \\
\hline $\begin{array}{l}\text { Unfasted } \\
18.00 \text { hours on Day } 2 \uparrow \text { to } 06.00 \text { hours on Day } 4 \\
18.00 \text { hours on Day } 3 \text { to } 06.00 \text { hours on Day } 5 \\
06.00 \text { hours on Day } 3 \text { to } 18.00 \text { hours on Day } 4 \\
06.00 \text { hours on Day } 4 \text { to } 18.00 \text { hours on Day } 5 \\
06.00 \text { hours on Day } 3 \text { to } 06.00 \text { hours on Day } 5 \\
\text { 18.00 hours on Day } 3 \text { to } 18.00 \text { hours on Day } 5\end{array}$ & $\begin{aligned} 10 / 12(84) \\
4 / 10(40) \\
4 / 11(36) \\
10 / 11(91) \\
10 / 11(91) \\
- \\
-\end{aligned}$ & $\begin{array}{rr}14 / 14 & (100) \\
7 / 13 & (54) \\
4 / 13 & (31) \\
12 / 14 & (86) \\
7 / 13 & (54) \\
3 / 13 & (23) \\
3 / 13 & (23)\end{array}$ & $\begin{array}{r}24 / 26(92) \\
11 / 23(48) \\
8 / 24(33) \\
22 / 25(88) \\
17 / 24(71) \\
3 / 13(23) \\
3 / 13(23)\end{array}$ \\
\hline
\end{tabular}

* Shown in parentheses.

+ Day $0=$ Day of appearance of vaginal plug.

TABLE 5

SUMMARY OF ANALYSIS OF VARIANCE OF THE EFFECTS OF FASTING ON FAILURE OF PREGNANGY (EXPERIMENTS BI a AND b)

\begin{tabular}{l|c|c}
\hline Source of variation & d.f. & Mean square \\
\hline $\begin{array}{c}\text { Time of day (T) } \\
\text { Day versus night }\end{array}$ & 1 & $1665^{* * *}$ \\
Day of treatment (D) \\
Day 3 versus others & 1 & 70 \\
Experiment (E) & & \\
Bl (a) versus B1(b) & 1 & 20 \\
Interactions & 1 & 39 \\
T $\times$ D & 1 & $278^{*}$ \\
$\mathbf{T} \times \mathbf{E}$ & 1 & 249 \\
D $\times$ E & 1 & 1 \\
T $\times$ D $\times$ E & $\infty$ & 68.4 \\
Error & \\
\hline
\end{tabular}

*** $P<0.001 ; * 0.01<P<0.05$.

The data were transformed to angles, $n=12$.

Effect of time of commencement of fasting on loss of body weight (Experiment B2)

The possibility that the differences between day and night results shown in Experiment B1 (a) and (b) were related to the amount of food in the gut at the beginning of the fast, was examined by recording body weights at the beginning and end of each fasting treatment. 
Groups of ten mice were fasted for $36 \mathrm{hr}$ from 18.00 hours on Day 2, 06.00 and 18.00 hours on Day 3, and 06.00 hours on Day 4. Unfasted mice were weighed at similar times to the fasted groups. All animals were killed on the 10th day after mating.

TABLE 6

CHANGES IN BODY WEIGHT AND FERTILITX IN MICE FASTED FOR SHORT PERIODS BEGINNING AT 06.00 HOURS OR 18.00 HOURS

\begin{tabular}{|c|c|c|c|c|}
\hline \multirow{2}{*}{ Fasting treatment } & \multicolumn{2}{|c|}{ Body weight (g) (Mean \pm S.E. $)$} & \multirow{2}{*}{$\begin{array}{c}\text { Change }(g) \\
(\text { Mean } \pm S . E .)\end{array}$} & \multirow[t]{2}{*}{ Fertility* } \\
\hline & Commencement of fast & End of fast & & \\
\hline $\begin{array}{l}\text { 18.00 hours Day } 2 \text { to } 06.00 \text { hours Day } 4 \\
06.00 \text { hours Day } 3 \text { to } 18.00 \text { hours Day } 4 \\
18.00 \text { hours Day } 3 \text { to } 06.00 \text { hours Day } 5 \\
06.00 \text { hours Day } 4 \text { to } 18.00 \text { hours Day } 5\end{array}$ & $\begin{array}{l}24 \cdot 7 \pm 1 \cdot 3 \\
24 \cdot 8 \pm 0 \cdot 5 \\
26 \cdot 2 \pm 0 \cdot 6 \\
25 \cdot 0 \pm 0 \cdot 6\end{array}$ & $\begin{array}{l}19 \cdot 9 \pm 1 \cdot 1 \\
20 \cdot 6 \pm 0 \cdot 4 \\
21 \cdot 4 \pm 0 \cdot 5 \\
20 \cdot 2 \pm 0 \cdot 6\end{array}$ & $\begin{array}{l}-4.8 \pm 0 \cdot 2 \\
-4 \cdot 2 \pm 0 \cdot 2 \\
-4 \cdot 8 \pm 0 \cdot 1 \\
-4 \cdot 8 \pm 0 \cdot 2\end{array}$ & $\begin{array}{l}2 / 10 \\
8 / 10 \\
5 / 10 \\
6 / 10\end{array}$ \\
\hline $\begin{array}{l}\text { Unfasted mice } \\
\text { Weighed } 06 \cdot 00 \text { hours } \\
\text { Weighed } 18.00 \text { hours }\end{array}$ & \multicolumn{2}{|c|}{$\begin{array}{l}25 \cdot 0 \pm 0.8 \\
26 \cdot 1 \pm 0 \cdot 6\end{array}$} & $+1 \cdot 2 \pm 0.7$ & $9 / 10$ \\
\hline
\end{tabular}

*Proportion pregnant 10 days after mating.
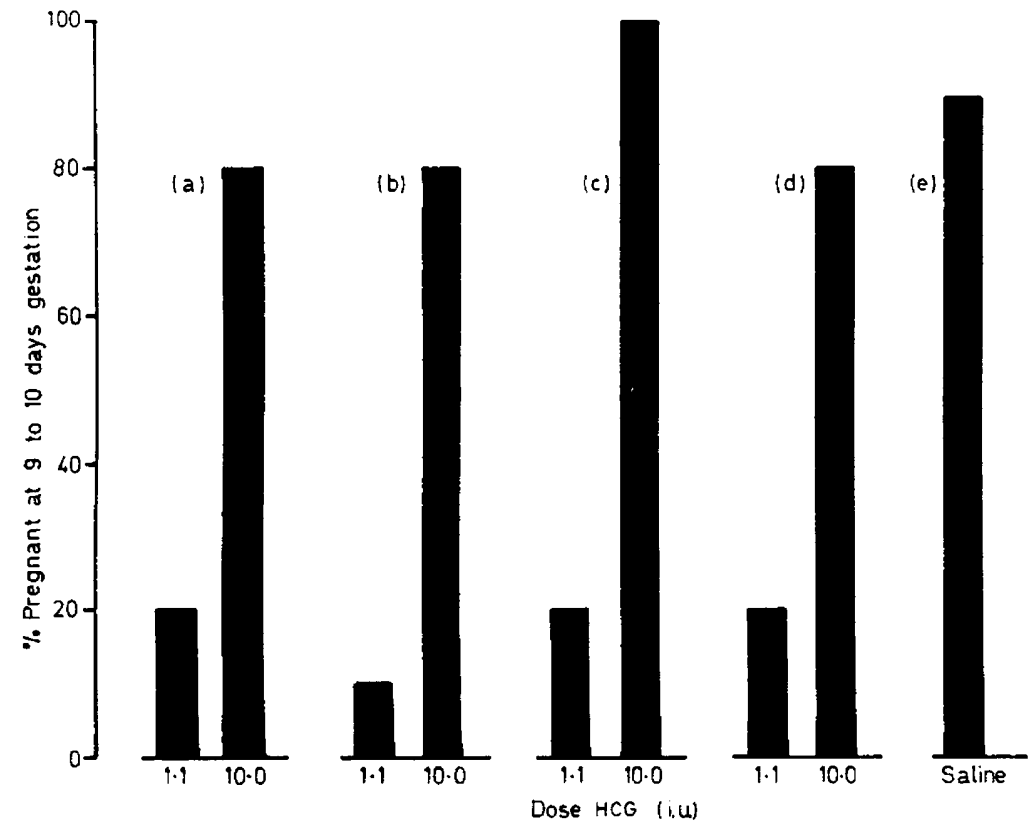

TexT-FIG. 4. The effect of HCG injected at noon on Days 3,4 and 5 on fertility at 9 to 10 days pregnancy, following 36 and $48 \mathrm{hr}$ of fasting. Day 0 is the day of appearance of the vaginal plug. (a) Fast commenced at 18.00 hours on Day 2 for $36 \mathrm{hr}$; (b) fast commenced at 06.00 hours on Day 3 for $36 \mathrm{hr}$; (c) fast commenced at 18.00 hours on Day 3 for $36 \mathrm{hr}$; (d) fast commenced at 06.00 hours on Day 3 for $48 \mathrm{hr}$; (e) unfasted.

The results of this experiment are shown in Table 6 . An analysis of variance revealed no relation between loss of body weight and the time or day on which the fast began. Pregnancy failure, however, was related to the time of commencement of the fast. 
Effect of administration of $\mathrm{HCG}$ (Experiment B3)

Fasts of $36 \mathrm{hr}$ were begun at 18.00 hours on Day 2 and at 06.00 and 18.00 hours on Day 3, for groups of ten mice. In addition, a group of mice was fasted for $48 \mathrm{hr}$, starting at 06.00 hours on Day 3. HCG $(1 \cdot 1$ i.u. or 10.0 i.u.) was injected into fasted mice at noon on each of Days 3,4 and 5. Unfasted mice were injected with saline at noon on each of Days 3,4 and 5. Both HCG and saline were stored in the refrigerator during the 3-day injection period. All mice were killed on Day 10.

The results are shown in Text-fig. 4 . The high dose of HCG $(10.0 \mathrm{i} . \mathrm{u}$.$) pre-$ vented the effects of fasting.

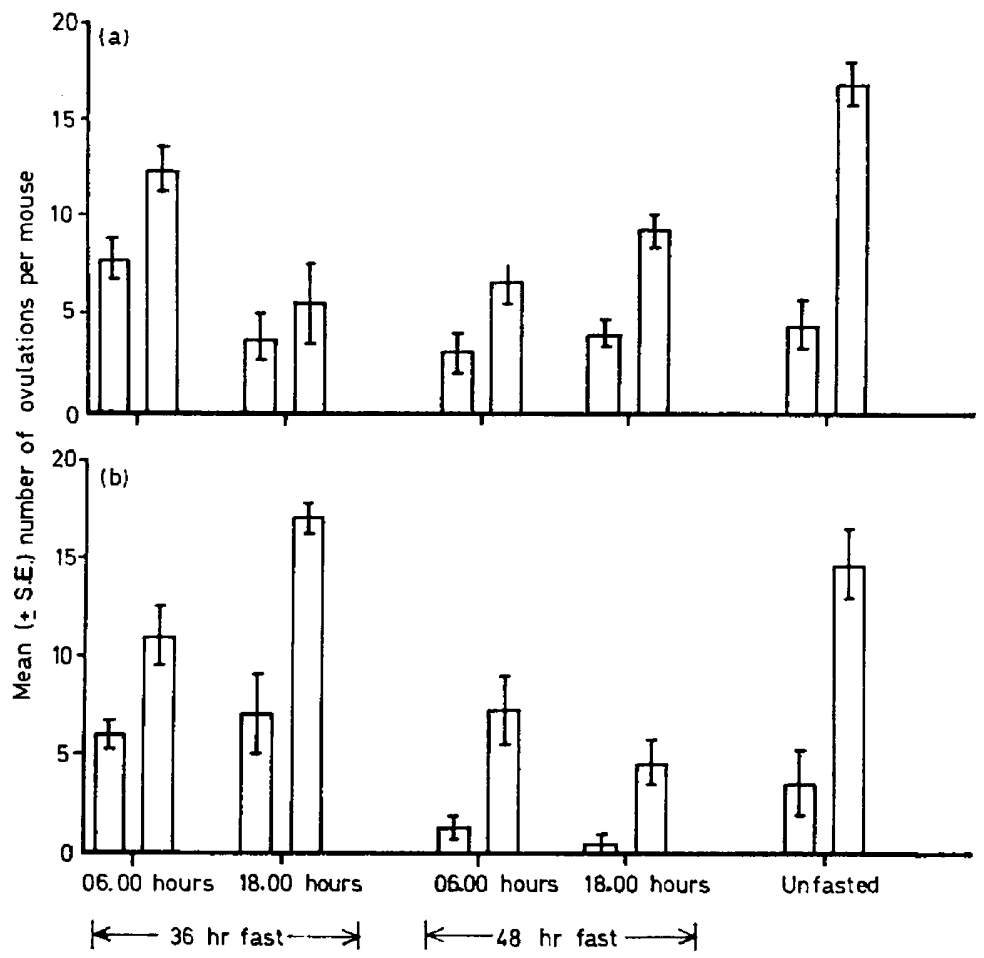

TEXT-FIG. 5. The ovulation response to HCG after 36- and 48-hr periods of fasting commenced at different times (Experiment B4). Day 0 is the day of injection with HCG. In each pair of columns the left represents the response to $1.5 \mathrm{i}$.u. and the right column that to 4.5 i.u. HGG. (a) Normal lighting regime, (b) reversed lighting regime.

Effect of fasting on ovulation in adult di-oestrous mice reared under opposite lighting regimes (Experiment B4)

Adult di-oestrous mice, of similar age and body-weight to those used in the pregnancy studies, but born and reared under two lighting regimes (see 'Materials and Methods'), were fasted for 36 or $48 \mathrm{hr}$, starting at 06.00 or 18.00 hours 2 days before an injection of HCG. The injections of HCG, chosen so as to fall on the linear portion of the log dose-response line for numbers of ovulations, were given at noon, and the number of ova in the ampulla of the oviduct was counted $24 \mathrm{hr}$ later. Twelve mice were used on each fasting treatment, and 
six of these were injected with either 1.5 or 4.5 i.u. of HCG. Unfasted mice received similar doses of HCG. The animals were kept on their respective lighting treatments throughout the test. The results are shown in Text-fig. 5, and an analysis of variance is summarized in Table 7 . It is evident that the 48-hr fast beginning at either 06.00 or 18.00 hours rendered the animals about one-half to one-third as sensitive as unfasted mice to HCG. A similar decline in response is observed in such mice when HGG is injected 3 to 4 min following hypophysectomy (unpublished observations).

Fewer ovulations occurred after a 36 -hr fast begun at 18.00 hours compared with 06.00 hours for normal mice, with an opposite trend for mice under the reversed lighting regime. Mice from different lighting treatments also responded differently after the 48-hr periods of fasting (see the interaction terms in the analysis, Table 7).

\section{TABLE 7}

SUMMARY OF ANALYSIS OF VARIANCE OF THE EFFECT ON OVULATION OF FASTING OF MICE ON NORMAL OR REVERSED LIGHT CYCLES (EXPERIMENT B4)

\begin{tabular}{|c|c|c|}
\hline Source of variation & $d . f$. & Mean square \\
\hline $\begin{array}{l}\text { Light cycle }(\mathrm{L}) \\
\quad \text { Normal versus reversed }\end{array}$ & $\begin{array}{l}1 \\
1\end{array}$ & 10 \\
\hline $\begin{array}{c}\text { Time of commencement of fast }(T) \\
06.00 \text { hours versus } 18.00 \text { hours }\end{array}$ & 1 & 13 \\
\hline $\begin{array}{l}\text { Length of fast }(\mathbf{P}) \\
36 \mathrm{hr} \text { versus } 48 \mathrm{hr}\end{array}$ & 1 & $490^{* * *}$ \\
\hline Dose of HCG (D) & 1 & $667 * * *$ \\
\hline $\begin{array}{l}\text { Interactions } \\
\mathrm{L} \times \mathrm{T} \\
\mathrm{L} \times \mathrm{P} \\
\mathrm{L} \times \mathrm{T} \times \mathrm{P} \\
\text { Remainder }\end{array}$ & $\begin{array}{l}1 \\
1 \\
1 \\
7\end{array}$ & $\begin{array}{c}68^{*} \\
143^{* * *} \\
201^{* * *} \\
9\end{array}$ \\
\hline Error & 79 & $11 \cdot 8$ \\
\hline
\end{tabular}

$* P<0.05 ; * * * P<0.001$.

\section{DISGUSSION}

The experiments of Everett \& Sawyer (1950), Everett (1956) and McCormack \& Meyer (1962) have shown the importance of time of day for pituitary function at certain stages in the life of the rat. The present studies (Experiments Al, A2 and A3), as well as the earlier reports (Lamond \& Braden, 1959; Lamond \& Bindon, 1966a), have employed the ovarian response to HCG in recently hypophysectomized mice to demonstrate what are interpreted as diurnal differences in pituitary function of immature mice. The fact that the gonadotrophic activity of HCG is dependent upon the presence of the test animal's pituitary had already been shown (Lamond \& Emmens, 1959). Further studies (Lamond $\&$ Bindon, 1966b) showed the effect of time of day of hypophysectomy on the biological assay of gonadotrophins, especially follicle stimulating hormone (FSH), using the HGG-augmentation test in immature mice. It seems likely, 
therefore, that there is an early afternoon release of gonadotrophin by the pituitary gland of the mouse.

It appears from Experiment A2 that immature mice in this colony have a single period of increased responsiveness each day, and that this occurs during the second half of the light phase of the daily light cycle. Reversal of the light cycle resulted in reversal of the time at which the increased response was observed. The mice used in the present studies were placed under the altered lighting regime from birth, so that no estimate of length of exposure required to bring about the change in response is possible. Timing of the critical period of LH-release in adult rats was observed to alter gradually during a 12-day period after abrupt alteration of the lighting schedule (Everett, 1952).

Unpublished observations indicate that this effect begins as early as the 15th day of life and that the time of its daily occurrence in young mice varies between individuals from as early as 11.00 hours to as late as 16.00 hours, with a peak around 14.00 hours. Such variation also exists in the LH-release phenomenon described by Everett \& Sawyer (1953).

The demonstration of diurnal variation in prolactin concentration in the rat's pituitary (Clark \& Baker, 1964), the existence of an afternoon peak in peripheral corticosteroid levels in the mouse (Halberg, Albrecht \& Bittner, 1959) and of diurnal variations in ovarian ascorbic acid levels of the pseudopregnant rat (Stevens, Owen, Fukushima \& Vorys, 1964) support the concept of diurnal pituitary function.

The experiments in part $\mathbf{B}$ of the present study indicate a diurnal aspect of pregnancy failure due to fasting. The effect does not appear to be due to differences in loss of body weight during the fast. Pregnancy failure following fasting probably results from an inhibition of hypophysial gonadotrophic function since HCG was able to overcome the effect (McClure, 1961; this paper, Experiment B3). Our results may be explained on the basis of an afternoon release of gonadotrophin by the pituitary, as follows: A fast of $36 \mathrm{hr}$ constitutes a stress to the pregnant mouse, but unless this stress corresponds to the time of a daily pituitary-release mechanism, it does not result in pregnancy failure. The time the fast begins is therefore important. Following commencement at 06.00 hours on Day 3, the stress of fasting apparently does not become operative until too late on Day 4; following replacement of feed at 18.00 hours, the animals have ample time to recover (approximately $20 \mathrm{hr}$ ) before the time of release on Day 5 . When begun at 18.00 hours on Day 3 , the release on Day 4 is again unaffected, but after replacement of feed at 06.00 hours on Day 5 , the recovery period (approximately $8 \mathrm{hr}$ ) is inadequate, the pituitary mechanism is inhibited and the chain of events initiated which results in failure of pregnancy. The absence of diurnal differences after 48 -hr fasts does not negate this theory. Whether such fasts begin at 06.00 or at 18.00 hours on Day 3, they are of sufficient duration to cause elimination of the release on Day 5 . The effects of fasting were largely overcome by injections of an adequate amount of HCG.

Adult, di-oestrous mice fasted at key times before injections of HCG, ovulated approximately one-third the number of ova released by controls. The response was similar to that obtained when mice are given HCG 3 to 4 min after hypophysectomy (unpublished results). Differences between mice from the two 
lighting regimes indicate that the mechanisms influenced by fasting are also influenced by the daily light-cycle.

\section{ACKNOWLEDGMENT}

NIH-LH-S5 was made available by the National Institutes of Health, Bethesda, Maryland, U.S.A.

\section{REFERENCES}

GLARK, R. H. \& BAKER, B. L. (1964) Circadian periodicity in the concentration of prolactin in the rat hypophysis. Science, N.Y. 143, 375.

EVERETT, J. W. (1952) Some factors affecting the success of pharmacological blockade of ovulation in rats. 7. clin. Endocr. Metab. 12, 923.

Everetr, J. W. (1956) The time of release of ovulating hormone from the rat hypophysis. Endocrinology, $59,580$.

Everett, J. W. \& SAwYer, C. H. (1950) A 24 hour periodicity in the "LH release apparatus" of female rats disclosed by barbiturate sedation. Endocrinology, 47, 198.

Everett, J. W. \& SAwYer, C. H. (1953) Estimated duration of the spontaneous activation which causes release of ovulating hormone from the rat hypophysis. Endocrinology, 52, 83.

Halberg, F., Albrecht, P. G. \& Bittner, J. J. (1959) Corticosterone rhythm of mouse adrenal in relation to serum corticosterone and sampling. Am. F. Physiol. 197, 1083.

LAMond, D. R. \& Bindon, B. M. (1966a) The biological assay of follicle stimulating hormone using hypophysectomized immature mice. 7. Endocr. 34, 365.

LAMOND, D. R. \& Bindon, B. M. (1966b) Effect of gonadotrophins on uterine growth of hypophysectomized mice. Nature, Lond. 209, 512.

LAMOND, D. R. \& BRADEN, A. W. H. (1959) Diurnal variation in response to gonadotrophin in the mouse. Endocrinology, 64, 921.

LAmond, D. R. \& EMmENs, C. W. (1959) The effect of hypophysectomy on the mouse uterine response to gonadotrophin. F. Endocr. 18, 251.

McClure, T. J. (1959) Temporary nutritional stress and infertility in female mice. F. Physiol., Lond. $147,221$.

MCClure, T. J. (1961) Pathogenesis of early embryonic mortality caused by fasting pregnant rats and mice for short periods. $\mathcal{7}$. Reprod. Fert. 2, 381 .

McCormack, C. E. \& Meyer, R. K. (1962) Ovulating hormone release in gonadotrophin treated immature rats. Proc. Soc. exp. Biol. Med. 110, 343.

Stevens, V. C., Owen, L., Fukushima, M. \& Vorys, N. (1964) Diurnal variation in ascorbic acid content of the ovary of the pseudo-pregnant rat. Endocrinology, 74, 493. 